\title{
Medicinal Plant Use Influenced by Health Care Service in Mestizo and Indigenous Villages in the Peruvian Amazon
}

\author{
Miki Toda $^{1}$, Misa Masuda ${ }^{2} \&$ Elsa L. Rengifo ${ }^{3}$ \\ ${ }^{1}$ Sustainable Environmental Studies, Graduate School of Life and Environmental Sciences, University of \\ Tsukuba, Tsukuba, Japan \\ ${ }^{2}$ Life and Environmental Sciences, University of Tsukuba, Tsukuba, Japan \\ ${ }^{3}$ Instituto de Investigaciones de la Amazoia Peruana, Iquitos, Peru \\ Correspondence: Miki Toda, Sustainable Enviornmental Studies, Graduate School of Life and Environmental \\ Sciences, University of Tsukuba, Tsukuba, Ibaraki, Japan. E-mail: s1230289@u.tsukuba.ac.jp
}

Received: December 9, 2016

doi:10.5539/jsd.v10n3p19
Accepted: March 9, 2017 Online Published: May 31, 2017

URL: https://doi.org/10.5539/jsd.v10n3p19

\begin{abstract}
Medicinal plants, as a type of non-timber forest products (NTFP), have been expected to support the livelihoods of people globally, especially in rural and forest areas in developing nations. As medicinal plants occupy a unique position, with direct repercussions for people's health and as a potential income resource, it is necessary to take the interaction with, and influence of, modern medicine into account when they are considered as a NTFP. This study pursued the influence of the health care service on medicinal plant utilization in mestizo and indigenous villages near secondary population agglomerations in the Peruvian Amazon. The study found some influence of the health care services on medicinal plant use in the study site, indicating that 1) medicinal plants are not necessarily a highly dependable approach for health care, 2) there are insufficient conditions for the development of a commercial market for medicinal plants, and 3) mestizo and indigenous households have similar health care utilization behaviours, although indigenous households are more affected by modern medicine, especially health care insurance, than the mestizo households. The health care service is an important factor for medicinal plant use for both health and livelihood. Without considering this factor, the potential of medicinal plants as NTFP cannot be fully understood.
\end{abstract}

Keywords: Amazon, forest resource, health care, medicinal plant, NTFP, tropical rain forest, rural urbanization

\section{Introduction}

Medicinal plants as a type of non-timber forest products (NTFP) have been expected to support the livelihoods of people, especially in rural and forest areas in developing nations. Medicinal plants hold a very unique position as they directly serve people's health and conversely represent a potentially large income resource if functional or medicinal properties are found in them. When medicinal plants are considered as a forest product, the interaction with, and influence of, modern medicine should not be overlooked.

In NTFP studies, whether NTFP support people's livelihoods is influenced by various factors including landscape, location, land use system (Wisersum, 1997; 2004; Ros-Tonen \& Wiersum, 2003; Chilalo \& Wiersum, 2011) or the type of relationship between people and forest (Wisersum, 1997; Byron \& Arnold, 1999). NTFP may support livelihood only as safety-nets (Shackleton \& Shackleton, 2004) or increase inequity in communities (Kusters, et al., 2006). Lawrence, et al. (2005) report that whether NTFPs help livelihood is not yet known because the factors and levels of people's dependency on the forest are not fully determined. While these studies examined various factors for NTFPs relating to people's livelihood, none of them paid much attention on potential influencers to the market of the target NTFPs, such as competing products or demand and supply conditions.

Whether plants are extracted from the forest or cultivated is also one of the relevant issues. Cultivation is desired for plant and forest conservation (Schippmann et al., 2006; Wiersum et al., 2006; Aguilar-Stoen \& Moe, 2007) and livelihood improvement (Ros-Tonen \& Wiersum, 2003; Belcher et al, 2005). However, Aguilar--Støen and Moe (2007) report that $3.3 \%$ of medicinal plants found in studies in eight countries were cultivated species. Another aspect of NTFP studies is whether plants are used for household consumption or trade (Godoy et al., 
2000; High \& Shackleton, 2000; Shackleton et al., 2002; Twine et al., 2003; Shackleton \& Shackleton 2004; Belcher, 2005). High and Schakleton (2000) show that more than $70 \%$ of plant products are consumed within households and the rest is traded in the case of a South African rural village. While these studies describe the use patterns of NTFP or medicinal plants, they hardly consider what influences such use pattern or demand. In the case of medicinal plant use, it is reasonable to ask whether the existence of modern medicine affects commercial potential as well as household consumption of medicinal plants. This may also impact whether the plants are cultivated or harvested from the forest.

For more than a quarter of a century, health care programs in developing countries based on modern medicine have been strengthened with concepts such as primary health care by the Alma Ata declaration in 1978 (World Health Organization, 1978) and universal health coverage in 2005 (World Health Organization, 2013). It is the case that folk and traditional medicine (hereafter, 'traditional medicine') has also been recognized as part of primary health care (Green, 1988; Kayne, 2010) to supplement the insufficient penetration of modern medicine, especially in remote or marginalized areas in developing countries. Medicinal plants, a part of the central method in most traditional medicines, have been also recognized as the essential in the primary health care (Akerele et al., 1991) and their conservation has been assured through the Chang Mai Declaration in 1988 (van Seters, 1997; Kathe, 2006). Economic growth and international initiatives would highly influence the provision of modern medicine, which may change medicinal plant use. The possible ripple effects of such long-term international initiatives both to support modern and traditional medicine, and the possible influence of ever expanding global commercialization in the last decade beg the question as to what is the condition to use medicinal plants for people in the remote areas in developing countries today.

While in some developing countries medicinal plants are important in primary health care (Estomba et al., 2006; Kitula, 2007; Lozada et al., 2006; Milliken \& Albert, 1997), reliance on modern medicine increases (Caniago \& Siebert, 1998; Vandebroek \& Balick, 2012) in other places. Choice between traditional and modern medicine depends on the users' social and cultural values with respect to each medicine (Janes, 1999; Wayland, 2004) or their knowledge of medicinal plants (Dahlber \& Trygger, 2009). Use and knowledge of medicinal plants can be dependent on age, gender, occupation, education, or location of plant habitation (Case et al., 2005; Quinlan \& Quinlan, 2007; Srithi et al. 2009; Meretika et al., 2010). Modernization and globalization are also considered to cause a loss of medicinal plant knowledge (Benz et al., 2000; Voeks \& Leony, 2004; Case et al., 2005; Voeks, 2007; Quinlan \& Quinlan, 2007; Srithi et al., 2009; Meretika et al., 2010). The presence of the health care service also affects the loss of knowledge about medicinal plants (Caniago \& Siebert, 1998; Vandebroek \& Balick, 2012). Meretika et al. (2010) show urbanization to be one of the important factors for the decrease in plant use and knowledge. All these studies show that the use and knowledge of medicinal plants varies depending on various factors, however, modernization and the presence of modern medicine appear as a key regarding the loss of knowledge, thus use of medicinal plants.

The Amazon basin including its Peruvian territory abounds with medicinal plants known through extensive ethnobotanical studies (Lacaze \& Alexiades, 1995; Mejia \& Rengifo, 1995; Communeros et al., 2007) and the use of the plants especially by indigenous people is well reported. While, in large cities in the Amazon basin, despite the easy access to modern medicine, active commercial activities relating to medicinal plants as much as overharvesting is concerned have also been reported (Galy et al., 2000; Shanely \& Luz, 2003). Unlike the large cities, however, indigenous people near a secondary city in the Peruvian Amazon tend to rely on modern medicine on the one hand, yet, the presence of modern medicine does not necessarily lessen medicinal plant use on the other (Toda et al., 2016). These studies indicate that urbanization may not necessarily result in a uniform use pattern of medicinal plants. Padoch et al. (2008) found unique patterns of consumption and knowledge in a rural-urban migration process within Amazonia, whereby urban migrants increase the demand for forest-derived products in rural areas. These studies indicate that the level of urbanization affects the demand for medicinal plants.

The Ministry of Health of the Peruvian Government includes a division, the National Centre for Intercultural Health (Centro Nacional de Salud Intercultural), whose responsibility is to oversee and understand traditional medicine and its cultural syndrome, which is not within a scope of modern medicine, and to compile medicinal plant information. Conversely, although Cotlear (2006) reports that Peru has inadequately financed its health care systems, the government created the Comprehensive Health Insurance system in 2001 (Seguro Integral de Salud, SIS), which intends to provide health services by giving priority to the poorer sections of the population. The SIS subscribers do not need to pay for health services in appointed health facilities. Although disparities between rural and urban and poor and non-poor regarding health and health service provisions still exist, the SIS has expanded health coverage especially in rural and poor areas (Francke, 2013). Taking account of the rapid 
economic growth of the country in the last two decades and its potential effect on rural areas, the Peruvian Amazon would be an appropriate field in which to examine peoples' utilization of medicinal plants in relation to modern medicine.

We aim to elucidate the commercial and health care potential of medicinal plants as a NTFP under the influence of health care service provision through a case study in the central Peruvian Amazon. The interaction between traditional medicine, including medicinal plant use, and modern medicine has been of interest within the field of medical anthropology. However, it has not been the case for NTFP studies to the best of our knowledge. In order to determine the influence of health care service on the use of medicinal plants, we assume urbanization in the Peruvian Amazon increases accessibility to modern medicine, and in turn, decreases medicinal plant use. The objectives of the study were to 1) examine medicinal plant use for health (self-consumption) and commercial purposes, 2) determine the level of use of modern medicine, and 3) assess the influence of modern medicine on the use of medicinal plants and their interaction through comparing the utilization between mestizo and indigenous people in villages near the city. The study was conducted in the second strata of population agglomeration in Amazonian cities in Peru because, unlike larger cities, secondary cities seem to provide ambivalent conditions for choosing health care methods, reflecting the insufficient penetration of modern medicine as well as for the lower level of commercial development associated with remoteness, yet with the pervading influence of economic development in the country (Toda et al., 2016).

\section{Methods}

\subsection{Site Selection and Descriptions}

The city of Contamana was chosen because it is remote enough, not having road connections with the largest cities in the Peruvian Amazon that have rapidly developed in the last decade, yet, it is not separate from the influence of the country's economic development and global commercialization. Contamana is located in the central Peruvian Amazon along the Ucayali River, the major tributary of the Amazon River, and between the two largest Peruvian Amazon cities; Iquitos with a population of 440,000 and Pucallpa with a population of 200,000 (Figure 1). Having over 20,000 residents, Contamana is the capital of Ucayali province, the southern frontier of Loreto Department and adjacent to Ucayali Department. It can only be accessed by boat along the Ucayali River or by plane from Iquitos, the capital of Loreto Department, located $440 \mathrm{~km}(840 \mathrm{~km}$ by river) north, and Pucallpa,

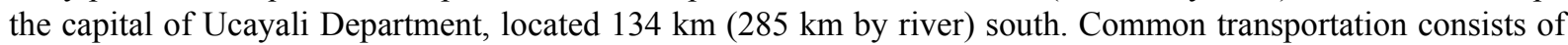
motorcycles and three wheelers, called moto-carro. The city is the regional commercial centre where people from not only surrounding but also remote villages travel five or six hours to come and sell agricultural and fishery products, their main livelihood. The Ucayali River is the sole means of transportation for many of the local people.

Two mestizo villages, named here m-1 and m-2, which adjacent to each other and an indigenous community of Shipibo, village S, were selected. They face the Ucayali River and are located in relatively close proximity, therefore the distance to the city is similar compared to other combinations of mestizo and indigenous villages. Mestizo are descendants of the Amerindian and Iberian peoples, and the Shipibo are the dominant indigenous ethnic group in the central Peruvian Amazon, dispersed mainly in Peru along the Ucayali River and partially living in Bolivian and Brazilian territories. Both mestizo and the Shipibo people around the study area generally practice slash-and-burn cultivation for living complemented by limited fishing and hunting. The Shipibo are well known as traditional users of a variety of medicinal plants (Enocaise et al., 2014). Village m-1, having 47 households, and Village m-2, having 34 households, are both located $13 \mathrm{~km}$ south of Contamana along the Ucayali River and it takes about 40 minutes by boat to get to the city. Both villages share the same port on the river, yet Village m-1 is located in upper land just above Village m-2. Village m-1 on the upper land has water distribution for several hours a day. People in Village m-2 use water from a communal well, a stream or the river. Village S had 39 households during the period of the field study and is located $18 \mathrm{~km}$ south of Contamana and a 5 minute walk inland from a port on the Ucayali River, at a tributary of the river. Village $S$ also has water distribution, yet people often use water from the river. There is no health care facility in these villages. People have to go to either a medical clinic staffed by a nurse and a technician, located in a village $4 \mathrm{~km}$ from Villages $\mathrm{m}-1$ and $\mathrm{m}-2$ and $9 \mathrm{~km}$ from Village $\mathrm{S}$ or a hospital in the city for medical treatment (Table 1). If there is not enough stock of medicinal drugs in the village, they must go to those health care facilities or the city to purchase medicinal drugs. Motor boats are the sole means of access to the city and most of the nearby villages. Not everyone has a boat, yet there are regular boats running from and to the city a few times a day. 


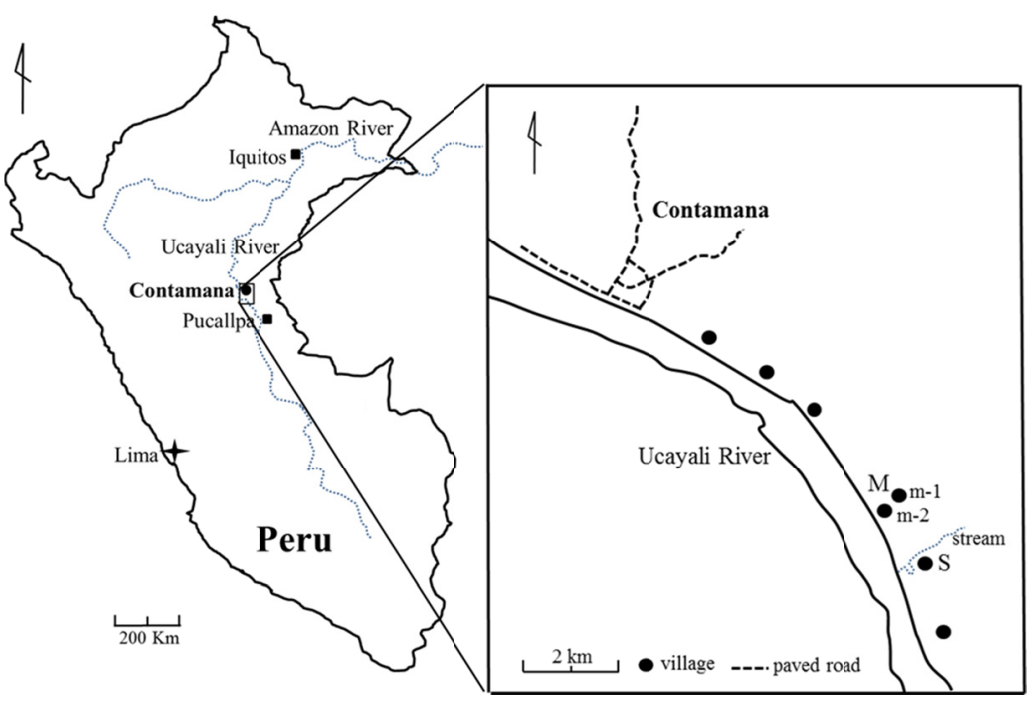

Figure 1. Study sites

\subsection{Data Collection and Analysis}

The data were collected in Villages m-1 and m-2 in February, 2014 and in Village S in July, 2014 with the permission of the head of each village. After obtaining signed informed consent following verbal and written explanations of the study, interviews with households were held based on a structured questionnaire regarding the use and practice of medicinal plants and health care services based on modern medicine as well as socio-economic information. Almost all householders resident in each village during the field study were interviewed. Either the household head or his wife in 25 out of 26 households in Village m-1, 21 out of 26 in Village $\mathrm{m}-2$ and all 39 households in Village $\mathrm{S}$ were interviewed. Although a few householders were unable to be interviewed in Villages m-1 and m-2 due to their absence, the survey was intended to be an inventory. Thus, two mestizo villages are treated collectively as a mestizo group designated Village M (Figure 1).

Table 1. Distance to health care services and household profile

\begin{tabular}{lll}
\hline & Village M & Village S \\
\hline Village location: distance to & & \\
\hline Hospital & $13 \mathrm{~km}$ & $18 \mathrm{~km}$ \\
Clinic & $4 \mathrm{~km}$ & $9 \mathrm{~km}$ \\
Pharmacies & $13 \mathrm{~km}$ & $18 \mathrm{~km}$ \\
\hline Respondents & & \\
\hline Total number & 46 & 39 \\
Average age & 38.8 & 38.1 \\
Average year of education & 5.5 & 6.5 \\
\hline
\end{tabular}

Information obtained from the households was analysed through qualitative and quantitative methods and statistical testing. The information regarding medicinal plant utilization is assessed according to frequency of use, plant species and frequency of commercial activities. Plants were identified by their local name, yet for reference purposes, scientific names were added based on local references provided by Mejia and Rengifo (1995) and IIAP (2010). To determine the influence of health care services on medicinal plants, modern medicine utilization, including the frequency of health care facility visits, medicinal drug purchases and health insurance subscription as well as perceptions of the efficacy and need for medicinal plants, were investigated through statistical testing (Figure 2). 


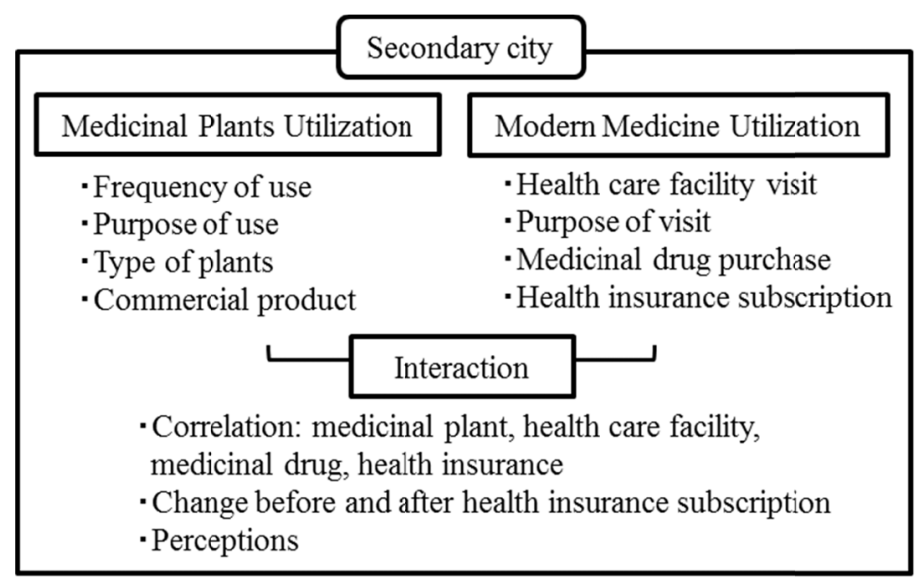

Figure 2. Study framework

\section{Results}

\subsection{Utilization of Medicinal Plants}

The general utilization of plants for health care purposes was determined through questions regarding the top five most frequently used medicinal plants in each household for home health care. In order to identify influences on the frequency of medicinal plant use per the last one year, basic demographic attributes were statistically tested for gender by t-test, and age, years of education and income by Spearman's rho. All attributes were not correlated to the frequency of medicinal plant use.

\subsubsection{Frequency of Medicinal Plant Use}

Households which used medicinal plants for home care in the last one year and those that did not comprised $87.0 \%$ and $13.0 \%$, respectively, of total responses in both villages; 40 and 6 households, respectively, in Village $\mathrm{M}$ and 34 and 5 in Village S. Among medicinal plant users, those who use medicinal plants were categorized as those daily (Daily Users), once a week or more but not daily (Weekly Users), once a month or more but less than once a week (Monthly Users), and less than once a month (Infrequent Users). Daily Users comprised 10 (21.7\%) of the total responses in Village M and 8 (20.5\%) in Village S; Weekly Users, 9 (19.6\%) and 17 (43.6\%); Monthly Users, $13(28.3 \%)$ and 7 (17.9\%); and Infrequent Users 8 (17.4\%) and $2(5.1 \%)$, respectively. If Daily Users and Weekly Users are assumed to be frequent users, the breakdown for Village M is $41.3 \%$ and $64.1 \%$ for Village S. In Village $\mathrm{M}$, those who use medicinal plants once a month or more total $70 \%$ in Village $\mathrm{M}$ and $82 \%$ in Village $\mathrm{S}$ (Figure 3). Overall, however, the frequency of medicinal plant use in the year between the two villages is not significantly different $(t(83)=-1.217, p>.05)$.

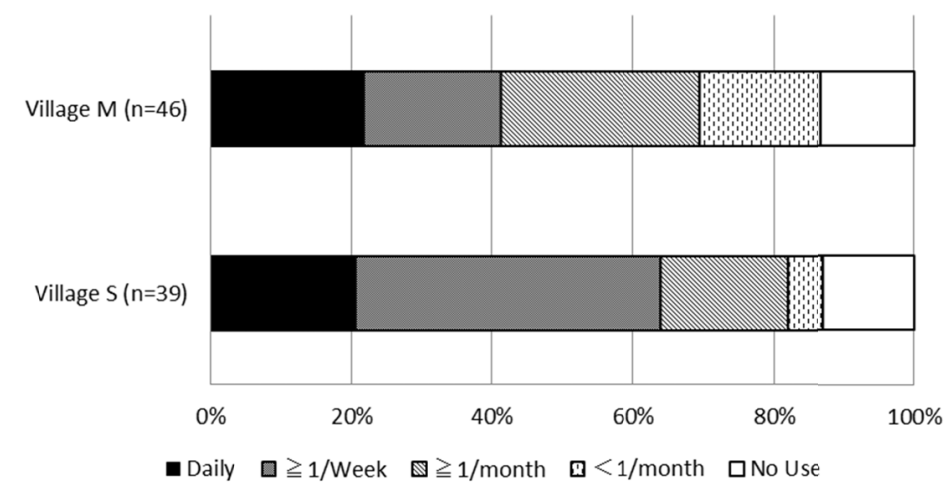

Figure 3. Household medicinal plant use

\subsubsection{Frequently Used Medicinal Plants}

The type of plants used and the location from which they were extracted was identified to determine the utilization of forest resources. Households in Village M cited use of 52 species. The total count for each species 
within their top five list was 156 . The most frequently cited plant was Malva (Malachra alceifolia), a herb, with 23 counts, representing 14.7\% overall; the second was Piñón Colorado (Jatropha gossypifolia), a shrub, with 20 counts, or $12.8 \%$. These are mostly planted around the houses including the following three frequently used plants: Mucura (Petiveria alliacea), a herb; Ajo Sacha (Mansoa alliacea), a vine; and Coca (Erythroxylum coca), a shrub. The leaves of the plants were mainly used except for Piñón Colorado from which the resin is frequently used in addition to the leave. The top five represent $44.8 \%$. Twenty-seven species out of 52 species were cited only once, representing $51.9 \%$ of the total count. In Village S, 39 species were cited, of which 21 species were cited only once, representing $53.8 \%$ of the total. The total count within their top five list was 147 . The top cited plant was Piñón Colorado with 33 counts, representing 22.4\%; the second was Malva with 28 counts (19.0\%), followed by Sangre de Grado (Croton lechleri), a tree; Piripiri (Eleutherine bulbosa), a herb; and Piñón Blanco (Jatropha curcas), a shrub; the top five represents 57.8\%. Sangre de Grado, of which only the resin is used, can be found in the forest, but is often planted. The other four species were mainly planted near the houses and their leafy parts were mainly used, except for the resin of Piñón Colorado and Piñón Blanco (Table 2).

Table 2. Top five most frequently used medicinal plants of villages $\mathrm{M}$ and $\mathrm{S}$

\begin{tabular}{|c|c|c|c|c|c|c|c|c|}
\hline \multirow{3}{*}{ Local name } & \multirow[b]{3}{*}{ Life form } & \multirow[b]{3}{*}{ Part used } & \multirow{2}{*}{\multicolumn{3}{|c|}{ Village M $(n=156)$}} & \multirow{2}{*}{\multicolumn{3}{|c|}{ Village S $(n=147)$}} \\
\hline & & & & & & & & \\
\hline & & & Rank & Count & $\%$ & Rank & Count & $\%$ \\
\hline Malva & $\mathrm{H}$ & leaf & 1 & 23 & 14.7 & 2 & 28 & 19.0 \\
\hline Piñón colorado & $\mathrm{S}$ & leaf/resin & 2 & 20 & 12.8 & 1 & 33 & 22.4 \\
\hline Mucura & $\mathrm{H}$ & leaf & 3 & 12 & 7.7 & $>5$ & & \\
\hline Ajo sacha & $\mathrm{V}$ & leaf & 4 & 9 & 5.8 & $>5$ & & \\
\hline Coca & $\mathrm{S}$ & leaf & 5 & 7 & 4.5 & $>5$ & & \\
\hline Sangre de grado & $\mathrm{T}$ & resin & $>5$ & & & 3 & 10 & 6.8 \\
\hline Piñón blanco & $\mathrm{S}$ & leaf/resin & $>5$ & & & 4 & 7 & 4.8 \\
\hline Piripiri & $\mathrm{H}$ & leaf & $>5$ & & & 4 & 7 & 4.8 \\
\hline Top five sub total & & & & 71 & 45.5 & & 85 & $57.8 \%$ \\
\hline Others & & & & 85 & 54.5 & & 62 & $42.2 \%$ \\
\hline Total & & & & 156 & 100.0 & & 147 & 100.0 \\
\hline
\end{tabular}

Note. Life form: $\mathrm{H}=$ herb, $\mathrm{S}=$ shrub, $\mathrm{T}=$ tree, $\mathrm{V}=$ =vine.

\subsubsection{Usage}

The purpose of medicinal plants was assessed through the top five most frequently used medicinal plants. Generally, medicinal plants are used for multiple purposes and some plants are mixed for a specific purpose. Although the usage list does not quantitatively, precisely represent these purposes, it shows the tendency of the villagers medicinal plant use. The households use a variety of the 52 species of medicinal plants in Village $\mathrm{M}$ and 39 in Village S. In Village M, among 35 different usages or symptoms, frequently mentioned were fever, cold, headache, the abdominal area including stomach, joints, and wounds, followed by fresh drink, cough, bronchitis, and diarrhea. In Village S, among the 31 usages or symptoms, frequently mentioned were fever, headache, wound, diarrhea, and cough, followed by cold, vomit, and abdominal area problems including stomach.

\subsubsection{Commercial Medicinal Plant Products}

People also purchase or sell medicinal plants, mainly in the form of remedies (tinctures). In Village M, 21 or $45.7 \%$, of the total respondents purchased medicinal plant remedies in Contamana in the last one year. Among them, only 4 respondents purchased once a month or more and the rest purchased only a few times a year. They all purchased remedies in the city. As for the sales of medicinal plants, only three people sold medicinal plants and the sales represented $16 \%$ or less of their total livelihood income. In Village S, 9, or $23.1 \%$, of the total respondents purchased them and three respondents purchased three times a year and were the most frequent purchasers. Only two households sold medicinal plants, and the sales represented $50 \%$ or more of their livelihood. One of the sellers was ordered to make specific remedies for indigenous ceremonies for tourists by an outsider. 
Table 3. Frequency of medicinal plant remedy purchase and sales in the last one year

\begin{tabular}{lrr}
\hline & $\begin{array}{c}\text { Village M } \\
(\mathrm{n}=46)\end{array}$ & $\begin{array}{c}\text { Village } S \\
(\mathrm{n}=39)\end{array}$ \\
\hline Respondents purchased & 21 & 9 \\
Respondents sold & 3 & 2 \\
\hline
\end{tabular}

\subsection{Utilization of Modern Medicine}

\subsubsection{Frequency and Purpose of Health Care Facility Visit}

General use of the health care service was determined by the question regarding the frequency of health care facility visits for household members in the last one year (Figure 4). Households that visited the health clinic in the closest village or the hospital in the city and those did not were 44 or $95.7 \%$ of the total of 46 households and 2 (4.3\%) respectively in Village M, and 36 or $92.3 \%$ of the total of 39 households and $3(7.7 \%)$ respectively in Village S. Those who visited health care facilities were categorized as users of once a month or more (Monthly Users), of less than once a month (Occasional Users), and of less than once every three months (Rare Users). Monthly Users in Villages M and S were 14 (30.4\%) and 8 (20.5\%) respectively. Occasional Users were 16 $(34.8 \%)$ and $5(12.8 \%)$ and Rare Users were $14(30.4 \%)$ and $23(59.0 \%)$ respectively. Overall, the frequency of health care facility visits in the year between the two villages is not significantly different $(t(83)=.446, p>.05)$. The purposes of the health care facility visits were similar in both villages and included headache, fever, diarrhea, cough, wound, pneumonia as well as regular medical checks for babies.

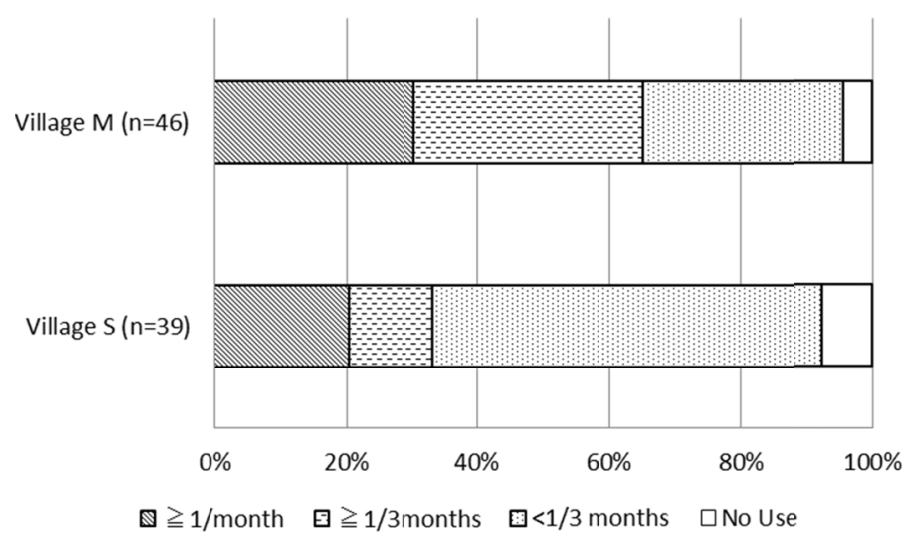

Figure 4. Frequency of household health care facility visit

\subsubsection{Purchase of Medicinal Drugs}

The general behaviour towards medicinal drug purchases for the respondents and their families in the last one year was determined through the frequency of medicinal drug purchases in the city, spending and usage (Figure 5). Households that purchased medicinal drugs in the city comprised 43 or $93.4 \%$ of the total 46 respondents and those that did not $3(6.5 \%)$ in Village M and in Village S, 32 or $82.1 \%$ of the total respondents of 39 and 7 (17.9\%) respectively. Those who purchased medicinal drugs were categorized as buyers of more than once a week (Weekly Buyers), of once a month or more and less than once a week (Monthly Buyers), of once every three months or more and less than once a month (Occasional Buyers), and of less than once three months (Rare Buyers). Weekly Buyers comprised $3(6.5 \%)$ in Village M and $2(5.1 \%)$ in Village S. Monthly Buyers in Village $\mathrm{M}$ and S comprised $2(4.3 \%)$ and 0; Occasional Buyers were 15 (32.6\%) and $12(30.7 \%)$; and Rare Buyers were $23(50.0 \%)$ and 18 (46.2\%), respectively. Overall purchasing frequency in the year between Village M and S was not significantly different $(t(83)=1.278, p>.05)$. Medicinal drugs purchased in Contamana were mainly for headache, stomach problems, diarrhea, cold, and cough in Village $\mathrm{M}$ and headache, fever and diarrhea in Village S. 


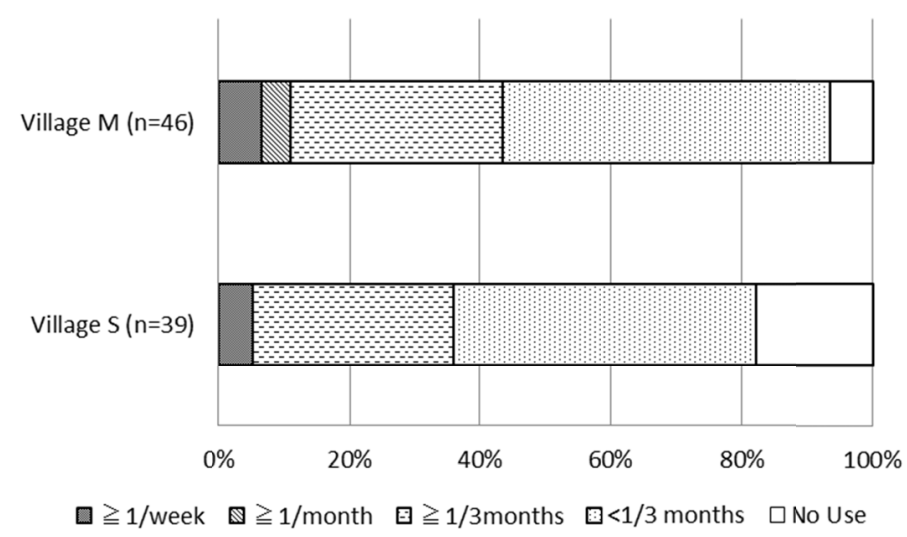

Figure 5. Frequency of household medicinal drug purchases

\subsubsection{Health Insurance Subscription and Influence on the Use of Modern Medicine}

In Village M, thirty households out of 46 subscribe to health insurance and 16 did not, and twenty-six out of 39 in Village S subscribe and 13 did not. There is no significant difference in holding health insurance between the two villages $\left(\chi^{2}(1, N=85)=.015, p>.05\right)$. The frequency of health care facility visits of the insurance subscribers and non-subscribers was compared (Figure 6). Overall, health insurance subscribers of both villages combined use the health care service significantly more than non-subscribers $(t=-2.543(64.864), p>.05)$. However, only Village $\mathrm{M}$ showed significant different $(t=-2.145(35.285), p<.05)$, but not Village $\mathrm{S}$ $(t=-1.234(37), p>.05)$. Among 30 insurance subscribers in Village M, 11 respondents (36.7\%) frequently visited the health care facilities more than before they held a health insurance subscription; 16 (53.3\%) saw no change; 2 (6.7\%) visited less; and 1 did not answer. Six respondents mentioned that they visited the health care facilities more frequently than before due to the insurance subscription and another four visit there more frequently due to having more illnesses than previously. Among 26 insurance holders in Village S, 18 respondents $(69.2 \%)$ visited the health care facilities more frequently than before subscribing to the health insurance; $5(19.2 \%)$ saw no change; 2 (7.7\%) visited less; and 1 gave no answer. Fifteen respondents visited the health care facilities more due to insurance subscriptions (Figure 7). Change in the frequency of health care facility visits after health insurance subscription significantly depended on village $\left(\chi^{2}(3, N=54)=7.195, p<.05\right)$; health insurance subscribers in Village $\mathrm{S}$ tend to visit more than those in Village $\mathrm{M}$ after subscription.
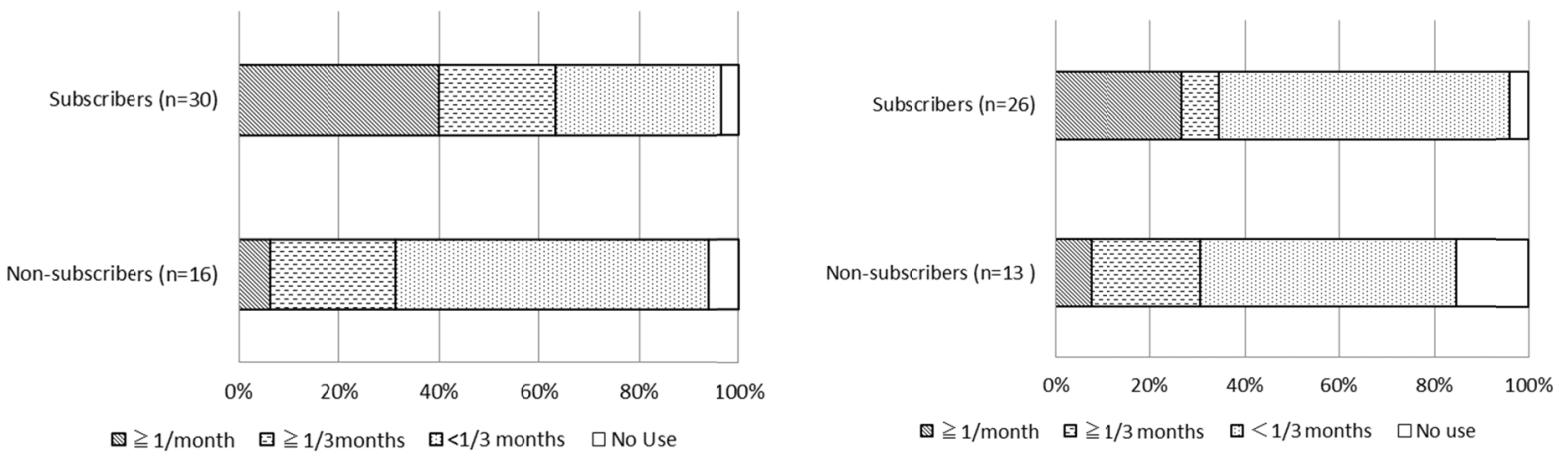

Figure 6. Frequency of health care facility visits by Village M (left) and Village S (right) 


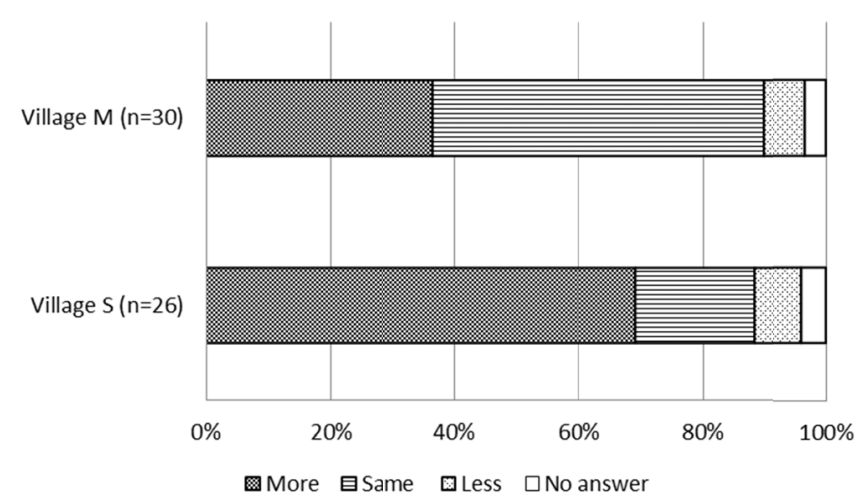

Figure 7. Frequency of the health care facility visit after health insurance subscription

In Village M, six (20.0\%) out of 30 insurance subscribers purchased more medicinal drugs in the city after taking out an insurance subscription and two respondents mentioned this being due to having more illnesses than before. Fourteen (46.6\%) purchased less medicinal drugs and of these 11 were due to the insurance subscription. Seven subscribers purchased medicinal drugs with the same frequency as before and 3 did not purchase any such drugs. In Village S, nine (34.6\%) of 26 insurance subscribers purchased more medicinal drugs in the city since the insurance subscription; $14(53.8 \%)$ purchased less and of these 11 mentioned that this was due to the insurance subscription; 1 saw no change; and 2 did not purchase any such drugs (Figure 8). Change in the frequency of medicinal drug purchase after health insurance subscription is not significantly different between the two villages $\left(\chi^{2}(3, N=56)=5.04, p>.05\right)$.

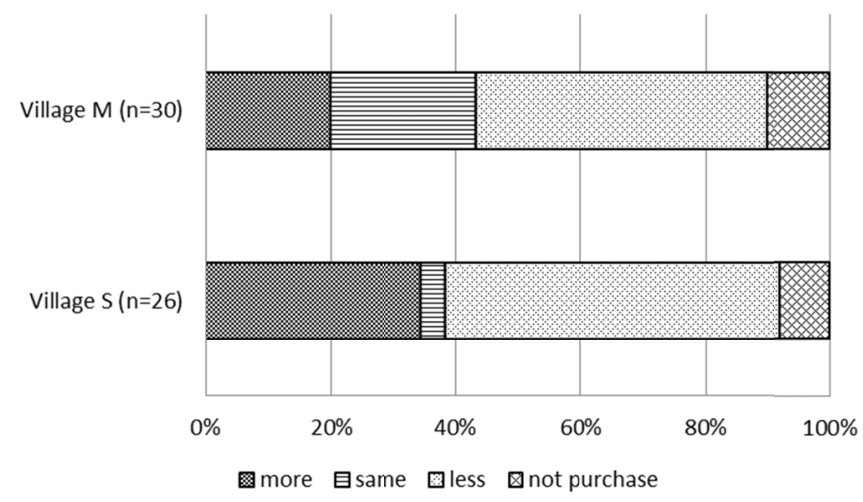

Figure 8. Household medicinal drug purchase frequency after health insurance subscription

\subsection{Influence of Modern Medicine on Medicinal Plant Use}

\subsubsection{Correlation between Use of Medicinal Plants and Modern Medicine}

In statistical testing, there was no significant correlation between the frequency of medicinal plant use and health care facility visits or medicinal drug purchases. However, the frequency of health care facility visits and purchases of medical drugs were significantly correlated both in Village $\mathrm{M}(r(46)=0.651, p<.01)$ and in Village $\mathrm{S},(r(39)=0.412, p<.05)$.

\subsubsection{Influence of Health Insurance on Medicinal Plant Use}

In Village M, 7 out of 30, or $23.3 \%$, of insurance subscribers used more medicinal plants since the start of their insurance holdings; 13 (43.4\%) used about the same; and 7 (23.3\%) used less, of which 5 responses indicated that this was due to the insurance subscription or visits to the clinic where they can receive free services and drugs using the insurance. Two did not respond and 1 did not use medicinal plants. In Village S, 6 (26.1\%) of insurance subscribers used more medicinal plants since their insurance subscription; 3 (13.0\%) saw no change; and $14(60.9 \%)$ used less, of which 8 responses indicated this was due to their insurance subscription or visiting the clinic (Figure 9). Change in the frequency of medicinal plant use after health insurance subscription is 
significantly different between the two villages $\left(\chi^{2}(4, N=52)=10.102, p<.05\right)$; health insurance subscribers in Village $\mathrm{S}$ have tended to use less medicinal plants than those in Village $\mathrm{M}$ after subscription.

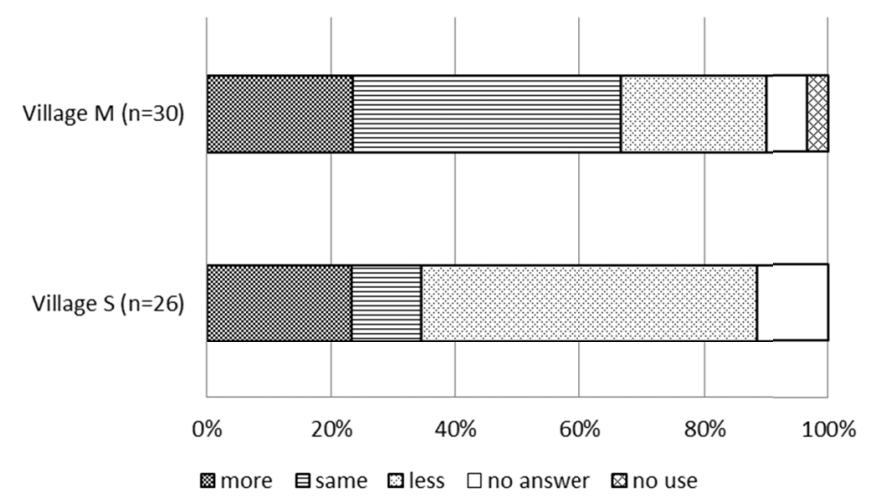

Figure 9. Medicinal plant use frequency after health insurance subscription

\subsubsection{Perception towards Medicinal Plant Use}

The perceptions towards medicinal plants were determined through questions about their belief in the efficacy of medicinal plants over medical drugs, willingness to learn medicinal plant knowledge and the importance of medicinal plant availability. In Village $\mathrm{M}, 50.0 \%$ of the total respondents answered that medicinal plants have more efficacy than medicinal drugs; $13.0 \%$ believed they have equal efficacy; $4.3 \%$ thought the efficacy depended on a case-by-case basis; $26.1 \%$ believed they had less efficacy; and $6.5 \%$ gave no answer. In Village S, $59.0 \%$ believed medicinal plants have more efficacy; $5.1 \%$ thought they had equal efficacy; $2.6 \%$ thought the efficacy depended on a case-by-case basis; $28.2 \%$ believed they had less efficacy; and $5.1 \%$ did not answer (Figure 10). There is no significant difference in the perception of efficacy between the two villages $\left(\chi^{2}(3, N=80)\right.$ $=1.938, p>.05$ ). Those who felt a need for learning medicinal plant knowledge represent $93.5 \%$ in Village $\mathrm{M}$ and $84.6 \%$ in Village S. Those who think it is a problem if medicinal plants are not available to use represented 45.7\% in Village M and 53.8\% in Village S. Among those who did not think it is a problem, 3 out of 24 in Village $\mathrm{M}$ and 11 out of 18 in Village $\mathrm{S}$ responded that this was due to the insurance subscription, medicinal drugs and health care facilities (Table 4).

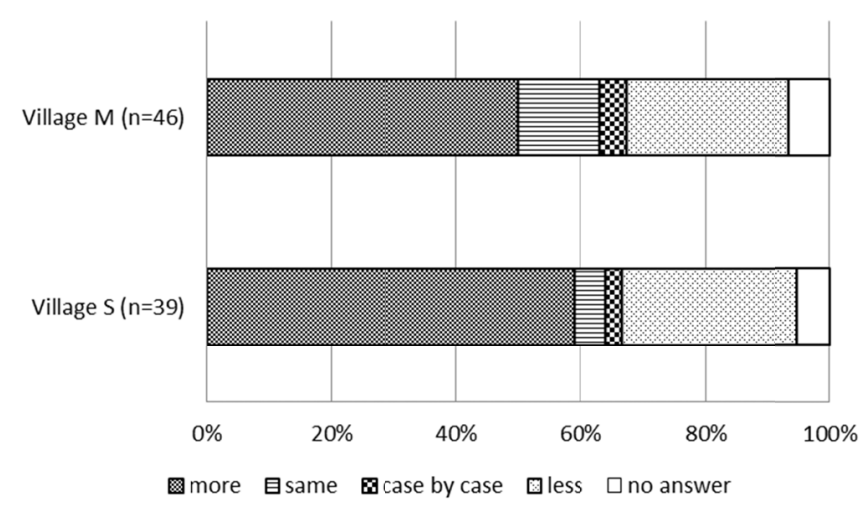

Figure 10. Perceptions of medicinal plants efficacy over medicinal drugs 
Table 4. Perceptions of the importance of medicinal plants (\%)

\begin{tabular}{lccccc} 
& \multicolumn{3}{c}{ Village $\mathrm{M}(\mathrm{n}=46)$} & \multicolumn{3}{c}{ Village $\mathrm{S}(\mathrm{n}=39)$} \\
\cline { 2 - 7 } & Yes & No & No answer & Yes & No \\
\hline $\begin{array}{l}\text { Do you feel need to learn } \\
\text { medicinal plants? }\end{array}$ & 93.5 & 4.3 & 2.2 & 84.6 & 15.4 \\
$\begin{array}{l}\text { Is it a problem if medicinal } \\
\text { plants cannot be available? }\end{array}$ & 45.7 & 52.2 & 2.2 & 53.8 & 46.2 \\
\hline
\end{tabular}

\section{Discussion}

\subsection{Utilization of Medicinal Plants}

The results show that people still use limited varieties of medicinal plants but not from forest. They also show that the usage differences between mestizo and indigenous people are not statistically significant. Although the percentage of daily users of medicinal plants was at a similar level between the two villages, households in Village $S$, the indigenous village, use medicinal plants more frequently than Village $M$, the mestizo villages, in total. This is consistent with a common understanding that indigenous people often use medicinal plants. However, while both villages use a variety of plants for medicinal purposes, their usages disproportionally slant towards the top five or even two plants. These top five most frequently used medicinal plants are basically not of forest origin but are cultivated nearby the houses in both villages, indicating that the villagers' use of medicinal plants is not a burden on forest resources. Although this does not accord with the study of Aguilar-Støen and Moe (2007) that only 3.3\% of medicinal plants are cultivated, Merétika et al. (2010) also found a similar situation in fishing communities in southern Brazil whereby the most frequently used plants were found in areas of easy access without significant impact on the environment due to the low utilization of forest resources. This tendency can also be interpreted as a decline in the use or knowledge of medicinal plants, at least in indigenous villages, as other studies have shown (Benz et al., 2000; Voeks \& Leony, 2004; Estomba et al., 2006; Monteiro et al., 2006; Quinlan \& Quinlan, 2007; Srithi et al., 2009; Teklehaymanot, 2009; Merétika et al., 2010), yet possibly in mestizo villagers as well. Unclear differences of medicinal plant knowledge between mestizo and indigenous echo the study by Campos and Thringhaus (2003) suggesting that "the boundary between traditional "indigenous" and "folk" knowledge becomes blurred.'

The study also shows that medicinal plants are not a source of income for many people. Less frequent purchasing and selling activities of medicinal plant products in both villages clearly indicates that people in and near a secondary city do not spend much on commercial medicinal plant products unlike those in larger cities in Amazonia (Galy et al., 2000; Shanley \& Luz, 2003). The results show that medicinal plants are not a profitable NTFP or support income for many. This is supported by the study of Pyhälä et al. (2006) reporting that NTFPs play a minor role in income generation. It is possibly the case that, as medicinal plants are available for people in villages as well as the city of Contamana, medicinal plant markets are not yet developed in the study area. The studies regarding the linkage between income generation of NTFP or forest resources and urban or market demand (Byron \& Arnold, 1999; Ruiz-Pérez et al., 2004; Padoch et al., 2008) support this proposition. Unless outsiders come and purchase them or sellers expand their commercial activities to larger cities, medicinal plants might not be expected to be a source of income for everyone. The availability of medicinal plants is partially responsible for the undeveloped market for commercial products and accompanied by people's incapability to expand the market beyond the secondary city, it fails to meet the expectation that medicinal plants provide support for their livelihoods.

\subsection{Utilization of Modern Medicine and its Influence on Medicinal Plant Use}

The result does not clearly show the relationship between use of medicinal plants for health and modern medicine. There were no significant differences in the purpose of use between the two health care methods in both villages. In Village M people more frequently visit health care facilities and purchase medicinal drugs than Village $\mathrm{S}$, although the differences are not significant. Use of the health care services and medicinal plants were not significantly related in either of villages. This may be because health care seeking behaviours can be influenced by geographical, socio-economic, cultural and organizational factors, the social status of women, the type of illness and access (MacKian et al., 2004, Shaikh \& Hatcher 2005; Grundy \& Annear, 2010). It may also be because medicinal plants are also used for preventive purposes, whereas a health care facility visit is not, even though the purpose of use between the two were not differentiated. The results show that health care facility 
visits and medicinal drug purchases were significantly correlated in both villages. This indicates a possible uniform behaviour towards modern medicine. The frequency of use including visits and purchases alone may not fully explain the influence of modern medicine on the use of medicinal plants.

On the other hand, health insurance subscription clearly influences health care seeking behaviour in both village $\mathrm{M}$ and $\mathrm{S}$ and it does more so in indigenous households, increasing health care facility visits and decreasing medicinal plant use. The results indicate that the health insurance system effectively works and promotes the use of more health care services. Therefore, as previous studies (Caniago \& Siebert, 1998; Vandebroek \& Balick, 2012) have found, it is safe to say that the health care service contributes to the decrease in medicinal plant use and knowledge, although not directly. What this study found is that indigenous people seemed to be more influenced by the health care service than the mestizo population, in turn, knowledge loss would be a concern, and too much knowledge may have already been lost.

\subsection{Perception of Medicinal Plants and Modern Medicine}

The results indicate that at least half of the target population tends to rely on modern medicine in both villages, yet indigenous people are more influenced by health care service provision. Even though more than half of the households in both villages believe that medicinal plants are more efficacious than medicinal drugs, in Village S, a higher percentage of households than in Village $\mathrm{M}$ also believe in the efficacy of modern medicine. In terms of willingness to learn about medicinal plants, Village $\mathrm{S}$ has a higher score than Village M. Moreover, among those who think losing medicinal plants is a problem there was no significant difference between the two villages, with more households associating the reasons with insurance holdings or health care service provisions in Village $\mathrm{S}$ than Village M. As a study by Compos and Ehringhaus (2003) suggests that part of the indigenous knowledge was acquired through the interaction with local people, today, the use and knowledge of medicinal plants may have been mixed between the two types of communities. Although culture is one of the factors in health care seeking behaviour (MacKian et al., 2004; Shaikh \& Hatcher, 2005; Grundy \& Annear, 2010), it is possible that culture has been transforming the knowledge of medicinal plants. The present study did not determine the reason why indigenous households were influenced more by health care services. This question is left to further investigation.

\section{Concluding Remarks}

This study suggests that the potential importance of considering the extensive background of a NTFP, such as conditions of competitive products and other influencers including urbanization and geographical location to the demand of the target NTFP, when the value of a NTFP for livelihood is concerned. The influencers on the demand also affect the utilization of resources from the forest. In the case of medicinal plants, the influencers affect health care behaviours of people. This result was based on a case study, yet suggests a direction for further study.

\section{Acknowledgements}

We express our sincere appreciation to the residents of Village $\mathrm{M}$ and $\mathrm{S}$ for their generous cooperation during our study. This study was partially funded by Sustainable Environmental Studies, Graduate School of Life and Environmental Sciences, University of Tsukuba.

\section{References}

Aguila- Støen, M., \& Moe, S. R. (2007). Medicinal plant conservation and management: Distribution of wild and cultivated species in eight countries. Biodiversity \& Conservation, 16, 1973-1981. http://dx.doi.org/10.1007/s10531-006-9125-7

Akerele, O., Heywood, V., \& Synge, H. (1991). The conservation of medicinal plants. Cambridge, UK: Cambridge University Press.

Belcher, B., Ruíz-Pérez, M., \& Achidiawan, R. (2005). Global patterns and trends in the use and management of commercial NTFPs: Implications for livelihoods and conservation. World Development, 33(9), 1435-1452. http://dx.doi.org/10.1016/j.worlddev.2004.10.007

Benz, B. F., Cevallos, E. J., Santana, M. F., Rosales, A. J., \& Graf, M. S. (2000). Losing knowledge about plant use in the Sierra de Manantlan Biosphere Reserve, Mexico. Economic Botany, 54(2), 183-191. http://dx.doi.org/10.1007/BF02907821

Byron, N., \& Arnold, M. (1999). What futures for the people of the tropical forests? World Development, 27(5), 789-805. http://dx.doi.org/10.1016/S0305-750X(99)00025-X

Campos, M. T., \& Ehringhaus, C. (2003). Plant virtues are in the eyes of the beholders: A comparison of known 
palm uses among indigenous and folk communities of southwestern Amazonia. Economic Botany, 57(3), 324-344. http://dx.doi.org/10.1663/0013-0001(2003)057[0324:PVAITE]2.0.CO;2

Caniago, I., \& Siebert, S. F. (1998). Medicinal plant ecology, knowledge and conservation in Kalimantan, Indonesia. Economic Botany, 52(3), 229-250. http://dx.doi.org/10.1007/BF02862141

Case, R. J., Pauli, G. F., \& Soejarto, D. D. (2005). Factors in maintaining indigenous knowledge among ethnic communities of Manus Island. Economic Botany, 59(4), $356-365$. http://dx.doi.org/10.1663/0013-0001(2005)059[0356:FIMIKA]2.0.CO;2

Chilalo, M., \& Wiersum, K. F. (2011). The role of non-timber forest products for livelihood diversification in Southwest Ethiopia. Ethiopian e-Journal for Research and Innovation Foresight, 3(1), 44-59. Retrieved from http://edepot.wur.nl/182898

Communeros de las communidades nativas Diamante, Palotoa-Teparo, Queros, Shipetiari, Santa Rosa de Huacaria. (2007). Uso tradicional de las plantas medicinales en las comunicades nativas de la Reserva de Biosfera del Manu: Una guía con apuntes de propagación de especies medicinales. London: Darwin Initiative Project.

Cotlear, D. (Ed.). (2006). A new social contract for Peru: An agenda for improving education, health care and the social safety net. A World Bank Country Study. Washington, DC: World Bank. Retrieved from http://siteresources.worldbank.org/INTPCENG/Resources/A_New_Social_Contract_for_Peru.pdf

Dahlberg, A. C., \& Trygger, S. B. (2009). Indigenous medicine and primary health care: The importance of lay knowledge and use of medicinal plants in rural south Africa. Human Ecology, 37, 79-94. http://dx.doi.org /10.1007/s10745-009-9217-6

Enocaise, T. J., Cauper Pinedo, S., Cumapa, C., Etene Etene, C., Panduro Pisco, G., Riva Ruiz, R., ... Urquia Odicio, R. (2014). 4.1.4 Ethnobotany of the Shipibo-Konibo. In M. Horak (Ed.), FOLIA. Universitatis Agriculturae et Silviculturae Mendelianae Brunesis VII:78-107. Brno, Czech Republic: Mendel University. Retreived from http://www.academia.edu/9759106/Ethnobotany_of_the_Shipibo-Konibo

Estomba, D., Ladio, A., \& Lozada, M. (2006). Medicinal wild plant knowledge and gathering patterns in a Mapuche community from north-western Patagonia. Journal of Ethnopharmacology, 103, 109-119. http://dx.doi.org/10.1016/j.jep.2005.07.015

Francke, P. (2013). Peru's comprehensive health insurance and new challenges for universal coverage. UNICO Studies Series 11. Washington DC: The World Bank. Retrieved from http://www.coopami.org/en/countries/countries/Peru/social_protection/pdf/social_prote ction01.pdf

Galy, S., Rengifo, E., \& Hay, Y.O. (2000). Factores de la organizacion del mercado de las plantas medicinales en Iquitos - Amazonia Peruana. Folia Amazonica, 11(1-2), 139-157. Retrieved from http://www.iiap.org.pe/Upload/Publicacion/Folia11_articulo7.pdf

Godoy, R., Wilkie, D., Overman, H., Cubas, A., Cubas, G., Demmer, J., McSweeney, K., \& Brokaw, N. (2000). Valuation of consumption and sale of forest goods from a Central American rain forest. Nature, 406, 62-63. http://dx.doi.org/10.1038/35017647

Green, E. C. (1988). Can collaborative programs between biomedical and African indigenous health practitioners succeed? Social Science \& Medicine, 27(11), 1125-1130. http://dx.doi.org/10.1016/0277-9536(88)90341-3

Grundy, J., \& Annear, P. (2010). Health-seeking behavior studies: A literature review of study design and methods with a focus on Cambodia. Working Paper Series, Health Policy and Health Finance Knowledge Hub 7, October 2010. Melbourne, Australia: The Nossal Institute for Global Health, University of Melbourne. Retrieved from http://ni.unimelb.edu.au/_data/assets/pdf_file/0020/542450/wp7.pdf

High, C., \& Shackleton, C. M. (2000). The comparative value of wild and domestic plants in home gardens of a South African rural village. Agroforestry Systems, 48 , http://dx.doi.org/10.1023/A:1006247614579

IIAP: Instituto de Investigaciones de la Amazonía Peruama. (2010). Base de datos plantas medicinales. IIAP, Iquitos, Peru. Retrieved

from http://190.187.112.98/webiiap/cdpublicaciones2011/documentos/pdf/piba/pu/22.pdf

Janes, C. R. (1999). The health transition, global modernity and the crisis of traditional medicine: The Tibetan case. Social Science \& Medicine, 48(12), 1803-1820. http://dx.doi.org/10.1016/S0277-9536(99)00082-9

Kathe, W. (2006). Revision of the 'Guidelines on the Conservation of Medicinal Plants' by WHO, IUCN, WWF 
and TRAFFIC. In R. J. Bogers, L. E. Craker, \& D. Lange, (Eds.), Medicinal and aromatic plants: Agricultural, commercial,ecological,Legal pharmacological and social aspects. Dordorecht, Netherlands: Springer. Retrieved from https://library.wur.nl/ojs/index.php/frontis/article/view/1227/799

Kayne, S. (2010). Introduction to traditional medicine. In S. B. Kayne (Ed.), Traditional medicine: A global perspective. London: The Pharmaceutical Press.

Kitula, R. A. (2007). Use of medicinal plants for human health in Udzungwa mountains forests: A case study of New Dabaga Ulongambi Forest Reserve, Tanzania. Journal of Ethnobiology and Ethnomedicine, 3(7). http://dx.doi.org/10.1186/1746-4269-3-7

Kusters, K., Achidawan, R., Belcher, B., \& Ruiz Peres, M. (2006). Balancing development and conservation? An assessment of livelihood and environmental outcomes of nontimber forest product trade in Asia, Africa, and Latin America. Ecology and Society, 11(2), 20. Retrieved from http://www.ecologyandsociety.org/vol11/iss2/art20/.

Lacaze, D., \& Alexiades, M. (1995). Salud para todos: Plantas medicinales y salud indigena en la cuenca del río Madre de Dios, Perú. Cusco, Peru: Centro de Estudio Regionales Andinos "Bartolomé de Las Casas".

Lawrence, A, Phillips, O, Ismodes, A. R., Lopez, M., Rose, S., Wood, D., \& Jose Farfan, A. (2005). Local values for harvested forest plants in Madre de Dios, Peru: towards a more contextualized interpretation of quantitative ethnobotanical data. Biodiversity and Conservation, 14, 45-79. http://dx.doi.org/10.1007/s10531-005-4050-8

Lozada, M., Ladio, A., \& Wigandt, M. (2006). Cultural transmission of ethnobotanical knowledge in a rural community of northwestern Patagonia, Argentina. Economic Botany, 60(4), 374-385. http://dx.doi.org/10.1663/0013-0001(2006)60[374:CTOEKI]2.0.CO;2

MacKian, S., Bedri, N., \& Lovel, H. (2004). Up the garden path and over the edge: Where might health-seeking behavior take us? Health Policy and Planning, 19(3), 137-146.

Mejia, K., \& Rengifo, E. (1995). Plantas medicinales de uso popular en la Amazonía Peruana. Lima, Peru: Agencia Espanola de Cooperacion International. Retrieved from http://www.iiap.org.pe/Upload/Publicacion/L017.pdf

Meretika, A. H. C., Peroni, N., \& Hanazaki, N. (2010). Local knowledge of medicinal plant in three artisanal fishing communities (Itapoa, Southern Brazil), according to gender, age, and urbanization. Acta Botanica Brasilica, 24, 386-394. Retrieved from http://www.scielo.br/pdf/abb/v24n2/a09v24n2.pdf

Milliken, W., \& Albert, B. (1997). The use of medicinal plants by the Yanomami Indians of Brazil, Part II. Economic Botany, 51(3), 264-278. http://dx.doi.org/10.1007/BF02862096

Monteiro, J. M., Paulino, U., Machado, E., Lima, E., \& Cavalcanti, E. L. (2006). Use patterns and knowledge of medicinal species among two rural communities in Brazil's semi-arid notheastern region. Journal of Ethnopharmacology, 105, 173-186. http://dx.doi.org/10.1016/j.jep.2005.10.016

Padoch, C., Brondizio, E., Costa, S., Pinedo-Vasquez, M., Sears, R. R., \& Siqueira, A. (2008). Urban forest and rural cities: multi-sited households, consumption patterns, and forest resources in Amazonia. Ecology and Society, 13(2), 2. Retrieved from http://www.ecologyandsociety.org/vol13/iss2/art2/

Pyhälä, A., Brown, K., \& Adger, N. (2006). Implications of livelihood dependence on non-timber products in Peruvian Amazonia. Ecosystems, 9, 1328-1341. http://dx.doi.org/10.1007/s10021-005-0154-y

Quinlan, M. B., \& Quinlan, R. J. (2007). Modernization and medicinal plant knowledge in a Caribbean horticultural village. Medical Anthropology Quarterly, 21(2), 169-192. Retrieved from http://www.jstor.org/stable/4499720

Ros-Tonen, M. A. F., \& Wiersum, K. F. (2003). The importance of non-timber forest products for forest-based rural livelihoods: an evolving research agenda. Presented at The International Conference on Rural Livelihoods, Forests and Biodiversity. 19-23 May 2003, Bonn, Germany. Retrieved from http://www.cifor.org/publications/corporate/cd-roms/bonn-proc/pdfs/papers/T2_FINAL_Ros-Tonen.pdf

Ruiz-Pérez, M., Belcher, B., Achdiawan, R., Alexiades, M., Aubertin, C., Caballero, J., ... Youn, Y. C. (2004). Markets drive the specialization strategies of forest peoples. Ecology and Society, 9(2), 4. Retrieved from http://www.ecologyandsociety.org/vol9/iss2/art4

Schippmann, U., Leaman, D. J., \& Cunningham, A. B. (2006). A comparison of cultivation and wild collection of medicinal and aromatic plants under sustainability aspects. In R. J. Bogers, L. E. Craker \& D. Lange 
(Eds.), Medicinal and aromatic plants (pp. 75-95). The Netherlands: Springer. http://dx.doi.org/10.1007/1-4020-5449-1_6

Shackleton, C., \& Shackleton, S. (2004). The importance of non-timber forest products in rural livelihood security and as safety nets: A review of evidence from South Africa. South African Journal of Science, 100(11 \& 12), 658-664. Retrieved from http://reference.sabinet.co.za/document/EJC96169

Shackleton, S. E., Shcakleton, C. M., Netshiluvhi, T. R., Geach, B. S., Balance, A., \& Fairbanks, D. H. K. (2002). Use patterns and value of savanna resources in three rural villages in South Africa. Economic Botany, 56(2), 130-146. http://dx.doi.org/ 10.1663/0013-0001(2002)056[0130:UPAVOS]2.0.CO;2

Shaikh, B. T., \& Hatcher, J. (2005). Health seeking behavior and health service utilization in Pakistan: Challenging the policy makers. Journal of Public Health, 27(1), 49-54. http://dx.doi.org/10.1093/pubmed/fdh207

Shanley, P., \& Luz, L. (2003). The impacts of forest degradation on medicinal plant use and implications for health care in eastern Amazonia. BioScience, 53(6), 573-584. http://dx.doi.org/10.1641/0006-3568(2003)053[0573:TIOFDO]2.0.CO;2

Srithi, K., Balslev, H., Wangpakapattanawong, P., Srisanga, P., \& Trisonthi, C. (2009). Medicinal plant knowledge and its erosion among the Mien (Yao) in northern Thailand. Journal of Ethnopharmacology, 123, 335-342. http://dx.doi.org/10.1016/j.jep.2009.02.035

Teklehaymanot, T. (2009). Ethnobotanical study of knowledge and medicinal plants use by the people in Dek Island in Ethiopia. Journal of Ethnopharmacology, 124, 69-78. http://dx.doi.org/10.1016/j.jep.2009.04.005

Toda, M., Rengifo Salgado, E. L., \& Masuda, M. (2016). Assessing medicinal plants as the linkage between healthcare, livelihood and biodiversity: A case study from native villages surrounding a second-tier city in the central Peruvian Amazon. Tropics, 25(2), 53-65. http://dx.doi.org/10.3759/tropics.MS15-07

Twine, W., Moshe, D, Netshiluvhi, T., \& Siphugu, V. (2003). Consumption and direct-use values of savanna bio-resources used by rural households in Mametija, a semi-arid area of Limpopo province, South Africa. South African Journal of Science, 99, 467-473. http://pdf.wri.org/ref/twine_03_consumption.pdf

van Seters, A. P. (1997). Forest based medicines in traditional and cosmopolitan health care. In G. Bodeker, K.K.S. Bhat, J. Burley, \& P. Vantomme (Eds.), Medicinal plants for conservation and health care. Rome: The Food and Agriculture Organization. Retrieved from http://www.fao.org/docrep/W7261e/W7261e04.htm

Vandebroek, I., \& Balick, M. J. (2012). Globalization and loss of plant knowledge: Challenging the paradigm. PlosOne, 7(5), e37643. http://dx.doi.org/10.1371/journal.pone.0037643

Voeks, R. A. (2007). Are women reservoirs of traditional plant knowledge? Gender, ethnobotany and globalization in northeast Brazil. Singapore Journal of Tropical Geography, 28, 7-20. http://dx.doi.org/10.1111/j.1467-9493.2006.00273.x

Voeks, R. A., \& Leony, A. (2004). Forgetting the forest: Assessing medicinal plant erosion in eastern Brazil. Economic Botany, 58, S294-S306. http://dx.doi.org/10.1663/0013-0001(2004)58[S294:FTFAMP]2.0.CO;2

Wayland, C. (2004). The failure of pharmaceuticals and the power of plants: medicinal discourse as a critique of modernity in the Amazon. Social Science \& Medicine, 58, 2409-2419. http://dx.doi.org/10.1016/j.socscimed.2003.09.023

Wiersum, K. F. (1997). Indigenous exploitation and management of tropical forest resources: An evolutionary continuum in forest-people interactions. Agriculture, Ecosystems, and Environment, 63, 1-16. http://dx.doi.org/10.1016/S0167-8809(96)01124-3

Wiersum, K. F. (2004). Forest gardens as an "intermediate" land-use system in the nature-culture continuum: Characteristics and future potential. Agroforestry Systems, 61, 123-134. http://dx.doi.org/10.1023/B:AGFO.0000028994.54710.44

Wiersum, K. F., Dold, A. P., Husselman, M., \& Cocks, M. (2006). Cultivation of medicinal plants as a tool for biodiversity conservation and poverty alleviation in the Amatola region, South Africa. In R. J. Bogers, L. E. Craker, \& D. Lange (Eds.), Medicinal and aromatic plants (pp. 75-95). The Netherlands: Springer. Retrieved from https://library.wur.nl/ojs/index.php/frontis/article/view/1222/794

World Health Organization. (1978). Declaration of Alma-Ata international conference on primary health care, Alma-Ata, USSR, 6-12 September 1978. Retrieved September 23, 2016, from 
http://www.who.int/publications/almaata_declaration_en.pdf

World Health Organization. (2013). The world health report 2013: Research for Universal Health Coverage.

Geneva: World Health Organization. Retrieved from
http://apps.who.int/iris/bitstream/10665/85761/2/9789240690837_eng.pdf?ua=1

\section{Copyrights}

Copyright for this article is retained by the author(s), with first publication rights granted to the journal.

This is an open-access article distributed under the terms and conditions of the Creative Commons Attribution license (http://creativecommons.org/licenses/by/4.0/). 